\title{
Gênese da \\ mercantilização \\ da terra urbana \\ no Pará \\ e os planos de expansão \\ da malha urbana para as \\ cidades de Santarém, Macapá e Cametá
}

\author{
Raul da Silva Ventura Neto, \\ Beatriz Mesquita Moura*
}

\begin{abstract}
Resumo No início da Primeira República do Brasil, a Constituição Federal concedeu aos governos estaduais autonomia para regulamentar as políticas de demarcação de terras. Particularmente no Estado do Pará, a regulamentação constitucional levou à doação de terras e à consequente discriminação dessas propriedades. Os planos urbanísticos das cidades de Santarém, Macapá e Cametá, concebidos por João de Palma Muniz, em 1904, também surgiram no mesmo contexto. Este artigo analisa o contexto institucional que envolve essas doações de bens e a elaboração dos planos urbanísticos acima mencionados. Além disso, usando fontes primárias e comparando as imagens aéreas atuais dessas cidades, o artigo discute o grau em que o projeto desenhado por Palma Muniz foi efetivamente executado.
\end{abstract}

Palavras-chave: planos de expansão, Palma Muniz, urbanismo na Amazônia.

Génesis de la comercialización de suelo urbano en Pará y los planes de expansión urbana para las ciudades de Santarém, Macapá e Cametá

Resumen Al comienzo de la Primera República, la constitución federal otorgó a los gobiernos estatales la autonomía para pronunciarse sobre las políticas de demarcación de tierras. Particularmente en el estado de Pará, el reglamento constitucional condujo a la donación de tierras y la consiguiente discriminación de estas propiedades. Los planes urbanísticos de las ciudades de Santarem, Macapa y Cameta, diseñados por Joao de Palma Muniz, también surgieron en el mismo contexto. Este artículo analiza el contexto institucional en torno a estas donaciones de activos y la elaboración de los planes urbanísticos antes mencionados. Además, utilizando fuentes primarias y comparando las imágenes aéreas actuales de estas ciudades, el artículo analiza el grado de ejecución efectiva del proyecto de Palma Muniz.

Palabras clave: planes de expansión, Palma Muniz, urbanismo en la Amazonia.
Genesis of the commercialization of urban land in Pará and the expansion plans for the cities of Santarém, Macapá e Cametá

\begin{abstract}
At the beginning of the Brazilian First Republic era, the Federal constitution granted State governments the autonomy to rule on land demarcation policies. Particularly in the State of Pará, the constitutional regulation led to the donation of land and the subsequent discrimination of these properties. Urban plans for the cities of Santarem, Macapa, and Cameta, designed by Joao de Palma Muniz, in 1904, also emerged in the same context. This article analyzes the institutional context surrounding these donations of assets and the elaboration of the above-mentioned urban plans. In addition, using primary sources and comparing the current aerial images of these cities, the article discusses the degree to which the project designed by Palma Muniz was effectively executed.
\end{abstract}

Keywords: urban plans, Palma Muniz, urbanism in Amazon region. 
A

Lei de Terras de $1850^{1}$ é o marco inicial nas tentativas de centralização das políticas de mercantilização da propriedade fundiária por meio da demarcação das chamadas Terras Devolutas², a partir da qual se buscava pôr fim ao caos que reinava na ocupação das terras inexploradas desde o tempo da Colônia (SAMPAIO, 1996, p. 196). A tentativa do Segundo Reinado de centralizar e, de certa forma, arbitrar conflitos agrários, cerceando poderes das elites regionais sobre o território, ao mesmo tempo em que postergou a efetiva demarcação das Terras Devolutas nas províncias (SILVA, 1996, p. 268), reforçou tensões políticas que seguiam latentes em torno da descentralização do Estado brasileiro, mesmo entre defensores da Monarquia Constitucional, como Tavares Bastos (CARVALHO, 2011, p. 149). Com o advento da Primeira República, o tipo de federalismo democrático que sai vitorioso na Constituinte de 1891 garante autonomia, soberania e independência às Unidades Federativas, mesmo sem haver um claro entendimento do conceito e da forma de convivência de duplas soberanias e autonomias na mesma federação (CARVALHO, 2011, p. 150).

Nesse arco temporal de quase meio século, entre a promulgação da Lei de Terras e o início da Primeira República, o Pará atravessava um surto de crescimento econômico por conta da exportação do látex da seringueira, que impulsionou tanto o desbravamento do território amazônico em busca de novas áreas de exploração, quanto a vinda de imigrantes para as principais cidades da região, buscando enriquecimento rápido com o "ouro negro" amazônico (WEINSTEIN, 1993). Durante a fase inicial da exploração gomífera, que coincide com as políticas fundiárias do Segundo do Reinado relacionadas à Lei de Terras ${ }^{3}$ e perdura de 1848 a 1880, a exploração do látex era realizada por inúmeras unidades caboclas de produção ribeirinhas, uma miríade de comerciantes volantes e alguns pequenos e médios aviadores (COSTA, 2012). Tratava-se de uma economia sustentada pelo conhecimento tácito do campesinato caboclo, disperso na região e herdado de sociedades indígenas anteriores à colônia, sobre o extrativismo e manejo apropriado do látex da seringueira (SILVA, 2017). Por conta disso, dependiam mais do conhecimento das populações tradicionais acerca do território amazônico do que propriamente de um extensivo processo de cercamento das propriedades que detinham concentração de seringueiras (VENTURA NETO, 2020).

* Raul da Silva Ventura Neto é Arquiteto e Urbanista, Professor da Faculdade e do Programa de Pós-Graduação em Arquitetura e Urbanismo da Universidade Federal do Pará, ORCID <https://orcid. org/0000-0001-7124-1002>. Beatriz Mesquita Moura é Discente de graduação em Arquitetura e Urbanismo da Faculdade de Arquitetura e Urbanismo da Universidade Federal do Pará, ORCID <https://orcid.org/00000002-0959-8075>.
Foi envolto nesse contexto que, em 1854, o aparato burocrático criado pelo Governo Imperial para discriminar as Terras Devolutas determinou um prazo para que todos os possuidores registrassem suas terras nas paróquias das províncias onde se localizavam, uma condição que garantia legitimação de posses autodeclaradas e uma posterior discriminação da propriedade pelos órgãos do Império (CAVALCANTE, 2005). No caso do Pará, Muniz (1907) cita um total de 22.611 declarações de posse entre os anos de 1854 e 1860, que, segundo defende Ferreira (2010), teria impacto sobre pequenas localidades dos municípios e sobre diferentes agentes sociais que buscavam regularizar as situações de terras que passariam para o controle particular, assegurando suas posses mediante o registro paroquial. 
1 Lei Imperial $n^{\circ} 601$, de 1850 (BRASIL, 1850).

20 termo "Terras Devolutas" referia-se às parcelas do território que não pertenciam a nenhum particular ou não estavam sob os cuidados do poder público em todas as suas instâncias, devendo tornar-se objeto de políticas de colonização ou de venda pelas instituições do Império Brasileiro (CAVALCANTE, 2005, p. 2).

3 Nesse caso, refiro-me particularmente ao Decreto $n^{\circ} 1.318$, de 1854, que determinava prazos para que todos os possuidores registrassem suas terras nas paróquias de suas respectivas freguesias.

4 No caso, trata-se das seguintes leis: i) Lei $n^{\circ} 82$, de 15 de setembro de 1892 (MUNIZ, 1904), que dispõe sobre a concessão dos patrimônios municipais; ii) Lei n 226 , de 6 de julho de 1894 (MUNIZ, 1904), que dispõe sobre a divisão territorial do Estado do Pará; iii) Lei $n^{\circ} 723$, de 2 de abril de 1900 (MUNIZ, 1904), que determina que as intendências municipais não podem conceder lotes de terrenos de seu patrimônio sem que tenham feito medir e demarcar.

5 Artigo $n^{\circ} 27$ da Lei $n^{\circ} 82$, de 1892 (MUNIZ, 1904).

6Idem.

7 Aforamento era um termo comum nos documentos oficiais da época. Ele faz referência ao regime de administração da terra, presente desde o Brasil Colônia, no qual o proprietário cedia o domínio útil da terra, mantendo o domínio pleno e o direito à cobrança de foros e outros tipos de impostos, como a décima urbana.

8 Lei n 723, de 2 de abril de 1900 (MUNIZ, 1904).

9 Palma Muniz denomina como Planos de Ampliamento o que neste artigo se denominou como Planos de Expansão.

10 Os projetos constam no livro Patrimônios dos conselhos municipaes do Estado do Pará (1904), no qual estão ainda outros projetos urbanos que não são tema ... continua na próxima página ...
O governo paraense assume a autonomia sobre as políticas de demarcação das terras devolutas a partir de 1891, durante a fase de maior atividade do ciclo gomífero no Pará, o que impacta definitivamente, em seu território, as estratégias definidas para a utilização das Terras Devolutas, estratégias essas que foram expressas em uma série de leis estaduais aprovadas na sequência da Constituição paraense de $1891^{4}$, na qual fica expresso que as terras devolutas deveriam ser usadas para a fundação de colônias, povoações e para a ampliação do patrimônio fundiário de municípios ${ }^{5}$, além de servirem para a abertura de estradas e extração de madeira para a construção naval. A concessão de terras devolutas para ampliar o patrimônio fundiário dos municípios respeitaria o limite de até 4356 hectares, dentro de uma zona de até três quilômetros de raio em torno da sede do município. Os Conselhos Municipais seriam responsáveis pelas respectivas medições e discriminações desse patrimônio ${ }^{6}$, ficando proibido o aforamento ${ }^{7}$ da terra e até mesmo a cobrança de qualquer tipo de imposto sobre a área, enquanto não fosse realizada a discriminação dos respectivos patrimônios ${ }^{8}$. Em complemento, a economia gomífera estimulava a constituição de um mercado fundiário urbano nas principais cidades do Estado, contribuindo para que a ampliação do patrimônio fundiário municipal passasse a ser orientada por um ordenamento racionalizado da terra urbana.

Nesse contexto, este artigo se propõe a analisar os Planos de Expansão ${ }^{9}$, elaborados pelo engenheiro paraense João de Palma Muniz, que se encontram como anexos do livro Patrimônio dos Conselhos Municipais do Estado do Pará, encomendado ao engenheiro paraense pelo Governo do Estado no início do século XX, com o objetivo de sistematizar informações a respeito do patrimônio fundiário dos municípios paraenses ${ }^{10}$. Ao fazer isso, Palma Muniz elaborou Planos de Expansão para as cidades de Santarém, Macapá11 e Cametá, sob forte influência dos preceitos da engenharia sanitária que pautaram, durante boa parte do século XIX, o reordenamento das grandes cidades europeias (CALABI, 2012).

O tipo de estudo a que este artigo se propõe, apesar de ainda embrionário, lança luz para um tema ainda pouco estudado na história do urbanismo brasileiro ${ }^{12}$, a saber: o modo como os projetos urbanos pautados nos preceitos da engenharia sanitária ocorreram no interior da Amazônia, ao longo do ciclo gomífero, por meio do trabalho de engenheiros paraenses formados na Escola Politécnica do Rio de Janeiro, celeiro do positivismo no Brasil e da propagação de um tipo de urbanismo orientado pela engenharia sanitária (RIBEIRO; ALVES, 2015, p. 62). Dentre eles, destacam-se Aarão Reis, autor do Plano de Belo Horizonte e da cidade de Soure, no Marajó; Nina Ribeiro, autor do Plano de Expansão para a Primeira Légua Patrimonial da cidade; Palma Muniz, cujos projetos serão analisados em sequência.

\section{A cidade pós-liberal e as primeiras formas de modernização no urbano brasileiro}

Na perspectiva de uma história global da cidade, Benévolo (2015, p. 575) classifica as grandes cidades construídas ou reformadas durante o século XIX como cidade pós-liberal: um modelo teórico de cidade que nasceu como resposta ao contexto de revoltas e epidemias urbanas, situação em que se entende que a livre iniciativa privada na transformação do solo urbano deveria ser limitada pelo poder local, por meio de regulamentações urbanas, ou por meio de grandes obras públicas de 
... continuação da nota $10 \ldots$

de análise neste artigo, como o desenvolvido para os núcleos agrícolas do Apeú, localizado no atual município de Castanhal, com acesso a partir da Estrada de Ferro de Bragança; para o núcleo urbano da colônia do Utauajury, no município de Monte Alegre, e para a Vila de Montenegro, atual município de Amapá, no Estado do Amapá; também projetos de loteamento rural para o município do Acará.

11 Até 1943, as terras do atual Estado do Amapá pertenciam ao Estado do Pará.

12 Com base nos trabalhos de Leme (1999), observa-se que nenhuma capital da região Norte do país foi citada nas pesquisas sobre os projetos de cunho higienista, mesmo que as cidades de Belém e Manaus fossem palco de substanciais Reformas Urbanas no início do século $X X$, a partir dos dividendos da exportação gomífera. Da mesma forma, em Segawa (2014), os exemplos de modernização urbana desse período citam apenas as cidades de Belém e Manaus, referindo-se principalmente à infraestrutura urbana que tinha sido instalada graças aos dividendos gerados pelo comércio da borracha.

13 Segundo Calabi (2012, p. 15), no início do século XIX, na Europa, havia vinte e duas cidades com mais de cem mil habitantes, distribuídos de maneira bem homogênea. Na Itália, havia seis; apenas Londres se aproximava do limiar de milhão de habitantes. Um século depois, na Europa, as cidades com mais de cem mil habitantes eram 123, enquanto as cidades com mais de um miIhão eram sete. Londres, que, em 1845 , superara os dois milhões, no início do século $X X$ atingiu sete milhões de habitantes. reordenamento do espaço. Mais do que isso, a cidade pós-liberal respondia a um novo contexto de acumulação capitalista e de avanço da urbanização que levou à formação de grandes cidades nos países de capitalismo tardio na Europa Ocidental ${ }^{13}$, impulsionadas por transformações produtivas e logísticas permitidas pela segunda revolução industrial.

Das propostas utópicas aos planos de expansão ou às brutais reformas urbanas de capitais, como Paris e Viena, a cidade pós-liberal buscava superar o arquétipo da cidade gerada pelos efeitos da primeira revolução industrial (MUNFORD, 2004). E fazia isso por meio da organização do Urbanismo como uma ciência que prometia controlar o crescimento e as transformações espaciais dos assentamentos urbanos com pretensões científicas e globalizantes (CALABI, 2012). A ciência do Urbanismo nasce com a perspectiva de produzir uma nova cidade ideal, cujo tecido urbano deveria ser orientado, ou reorientado, para funcionar a favor dos modernos serviços públicos de água, esgoto, gás, eletricidade, transporte de massa, dentre outros (MUNFORD, 2004).

Uma das formas mais significativas de intervenção do Estado na produção ou reestruturação do espaço urbano teve como mote o controle sobre as epidemias que proliferavam nas cidades da Europa e das Américas, principalmente. Das cidades europeias emanaram as primeiras grandes propostas de reordenamento urbano que buscavam consolidar uma cidade cientificamente orientada pela medicina social, em confluência, ou até mesmo em disputa, com as novas tecnologias que a engenharia sanitária desenvolvia para o abastecimento de água e tratamento de resíduos sólidos urbanos (HERCE, 2015). Em pouco tempo, as principais cidades do velho continente assistiram à implantação de modernas redes de abastecimento de água e esgoto, alinhadas a grandes planos de expansão urbana e saneamento para as cidades, como é o caso da cidade de Nápoles, na Itália (CALABI, 2012), ou mesmo a projetos de desenvolvimento econômico que articulavam um extensivo programa de reforma urbana às estratégias de centralização do capital e formação de um mercado de capitais vigoroso e competitivo, como foi o caso da reforma do Barão de Haussmann, em Paris (HARVEY, 2015).

No Brasil, esse novo paradigma de modernização urbana seria conduzido, sobretudo, por engenheiros formados nas escolas politécnicas do Rio de Janeiro e de São Paulo, tais como: Saturnino de Brito, Theodoro Sampaio e Lourenço Baeta Neves (LEME, 1999). Como sintetiza Segawa (2014), os engenheiros se colocavam como agentes de modernização, apostando na ciência e na técnica como instrumentos de progresso material para o país e codificando o urbanismo no Brasil dentro de uma visão racionalizadora e integrada de interferência na cidade.

Como grandes eventos representativos nas formas de modernização urbana, nesse período de passagem do século XIX para o XX, estão o projeto e a construção de Belo Horizonte, sob coordenação do engenheiro Aarão Reis, e a ocorrência das grandes intervenções urbanas no tecido da cidade colonial, como as conduzidas na gestão de Pereira Passos, na cidade do Rio de Janeiro. Não menos importante, encontra-se a elaboração de grandes planos urbanísticos e de saneamento para diversas cidades no país, com destaque para os projetos de Saturnino de Brito, para Recife, e de Santos e Campos, para o Estado do Rio de Janeiro (SEGAWA, 2014). 
14 Atualmente o acervo com as obras, os trabalhos e manuscritos que Palma Muniz produziu em vida estão de posse do Instituto Histórico e Geográfico do Pará. Para um compilado do conteúdo dos trabalhos publicados por Palma Muniz, ver: Stoll e outros (2019).
Especialmente em Belém, mas também nas cidades de Santarém, Macapá e Cametá, como se analisa na sequência, foram os Planos de Expansão urbana para o patrimônio fundiário municipal que simbolizaram os eventos de modernização sobre estruturas urbanas herdadas da Amazônia colonial. Em sua totalidade, constituem-se como projetos elaborados por engenheiros civis paraenses, funcionários públicos, em sua maioria, formados na Escola Politécnica do Rio de Janeiro, celeiro do positivismo no Brasil e da propagação da denominada engenharia sanitária (RIBEIRO; ALVES, 2015, p. 62).

Dentre esses profissionais, o nome mais conhecido se tornaria o de Aarão Reis, nascido em Belém, no ano de 1853, e graduado em engenharia pela Politécnica do Rio de Janeiro, em 1874. Ele foi autor do Plano de Expansão para a cidade de Soure, no arquipélago do Marajó. Assim como Aarão Reis, o engenheiro João de Palma Muniz graduou-se em Geografia e Engenharia pela Escola Politécnica do Rio de Janeiro, em 1899, e foi autor dos Planos de Expansão analisados neste artigo. Palma Muniz foi um dos mais profícuos intelectuais de sua geração, sócio fundador do Instituto Histórico e Geográfico do Pará e da Escola de Agronomia e Veterinária do Pará, em 1917 e 1918, respectivamente, além de diretor da seção de obras públicas do Estado, entre 1901 e 1927. Além de engenheiro, destacou-se principalmente como geógrafo e historiador, com trabalhos de envergadura sobre os limites estaduais, divisão territorial e sobre o registro de terras devolutas do Estado que ainda guardam informações valiosas e não publicadas sobre o ordenamento territorial do Pará nas primeiras décadas do século $X X^{14}$.

\section{Dos rossios aos Planos de Expansão: a forma de gerir e ordenar a terra urbana em Belém durante o século XIX}

Assim como a cessão de sesmarias a particulares, a doação de terras para a formação do patrimônio fundiário das Câmaras Municipais era uma tradição portuguesa muito anterior à colonização do Brasil. Via de regra, uma parcela desse patrimônio fundiário era dividida entre os habitantes da cidade, aforada a particulares que passavam a ter o domínio útil da terra sobre a qual poderiam edificar, devendo, a partir daí, recolher impostos para a Câmara. O restante do patrimônio era tradicionalmente conhecido como o rossio da cidade, utilizado como espaço comunal dos habitantes daquele núcleo urbano, para daí ser paulatinamente aforado ou incorporado à malha urbana, de acordo com a expansão da cidade (FONSECA, 2011). Dos municípios paraenses, Belém apresenta a doação mais antiga de patrimônio fundiário, uma légua de terras a contar do marco de fundação da cidade, datada de 1627, mas com a ocorrência da primeira demarcação apenas em 1703 e reconfirmação em 1851 (MUNIZ, 1904).

Se se tomar o caso de Belém como base para entender como se dava a gestão do patrimônio fundiário dos outros municípios analisados neste artigo, observa-se que, em Belém, a partir das determinações da Lei de Terras de 1850, de demarcar terras devolutas e inviabilizar a posse sobre a terra, aprofundou-se um processo de cerceamento de ocupação da Primeira Légua Patrimonial que não fosse por meio do aforamento. Com o crescimento urbano decorrente da exploração do látex, que impactou mais diretamente Belém, mas que reverberou também sobre as cidades de médio porte do Estado (VICENTINNI, 2004), os aforamentos da Primeira Légua passaram a se articular com Plantas de Loteamento para novos bairros, elaborados pelos engenheiros da Câmara Municipal a partir da década de 1860, que posteriormente se conectaram ao Plano de Expansão de Belém. 
Figura 1: Plano de Expansão de Belém produzido por Nina Ribeiro entre 1883 e 1886. Fonte: Muniz (1904, n. p).
O Plano de Expansão de Belém, produzido para orientar a ocupação do que restava do rossio da Primeira Légua Patrimonial de Belém (figura 1), consta no trabalho de Palma Muniz como anexo do capítulo que trata do patrimônio fundiário de Belém e aparece como de autoria do engenheiro paraense Manoel Odorico Nina Ribeiro, engenheiro da Câmara Municipal de Belém. Segundo Duarte (1997), o Plano teria sido produzido entre os anos 1883 e 1886 por Nina Ribeiro, após pedido de nova demarcação da Primeira Légua em 1881. No Plano, é possível observar a definição de quatro setores de malha ortogonal, que se comunicam entre si e com o núcleo antigo de ocupação da cidade pelo prolongamento dos seus principais eixos de penetração, transformando-se em geratrizes para o desenho da área de expansão (DUARTE, 1997, p. 57).

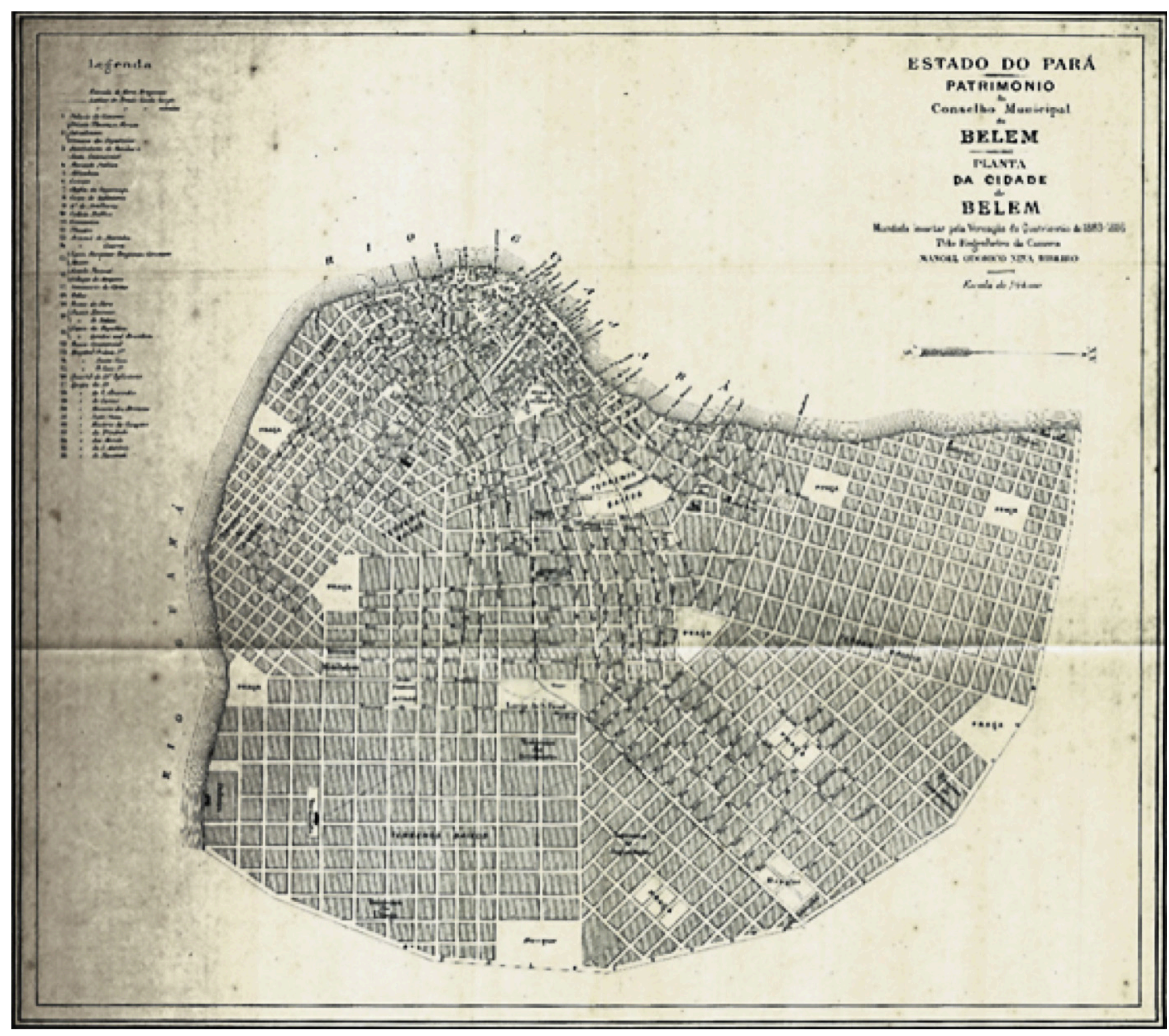


15 Atualmente essa área da cidade corresponde à totalidade ou a partes dos bairros de Fátima, Umarizal, Nazaré, São Brás, Marco, Pedreira, Jurunas, Batista Campos e Condor. Nas pesquisas documentais, foi possível localizar apenas uma versão da Planta de Loteamento para o bairro da Pedreira; no caso da Planta de Loteamento para o bairro do Jurunas, foram encontradas apenas evidências do documento nos termos de aforamento, contudo não foi possível localizar nenhuma cópia do documento no acervo histórico da Prefeitura de Belém até o momento de finalização do artigo.

16 Nesse material, a cada aforamento concedido, registrava-se a data do aforamento, os dados do enfiteuta e as características do bem aforado (FISCHER; BENATTI, 2017).

17 Cito aqui alguns exemplos de descrição encontrados nos termos de aforamento. Para a Planta de Loteamento do Bairro da Pedreira: [lote na] "estrada Visconde de Inhaúma, quarteirão 41, lote A; medindo 453 braças quadradas, 18 braças de frente, 42 braças de fundos, entestando pelo lado direito com o terreno concedido a Joaquim Estevam Ferreira de Campos e pelo lado esquerdo com a Travessa Alferes Costa" (FISCHER; BENATTI, 2017 p. 256). Para a Planta de Loteamento do Bairro do Jurunas: "200 braças quadradas de terreno equivalentes a 10 braças de frente na rua dos Timbiras com 20 de fundos, entestando pelo lado direito com o terreno concedido a Jose Agostinho da Silva Rebello e pelo lado esquerdo Cônego Bernardino Henriques Diniz, no quarteirão M sob o número 09 e 10" (FISCHER; BENATTI, 257).
Até o ano de 1904, conforme registrou Palma Muniz, o Plano de Expansão para a Primeira Légua Patrimonial de Belém havia sido apenas parcialmente executado, consolidando quadras em regiões de cotas mais altas e evitando a ocupação de regiões de várzea e alagáveis da cidade. Em grande medida, as quadras que Palma Muniz registrou em 1904 haviam sido abertas, por volta de 1860, pela Câmara Municipal, tanto para acomodar os imigrantes que afluíam a Belém na busca de se beneficiar da economia da borracha, quanto para atender às necessidades de investimento em terra urbana que a elite gomífera demandava, visto que imóveis e terra urbana passaram a lastrear empréstimos necessários para a extração do látex no interior da floresta (WEINSTEIN, 1993; VENTURA NETO, 2020).

A articulação entre o aforamento e a expansão da malha urbana para novas áreas da Primeira Légua era guiada por ao menos dois documentos, nos quais não se observa registro de autoria: a Planta de Loteamento do bairro da Pedreira e a Planta de Loteamento do bairro do Jurunas ${ }^{15}$. A elaboração das plantas de loteamentos servia à Câmara Municipal para adequar os pedidos de aforamento aos limites dos novos logradouros, alinhando o pedido às quadras e aos lotes previamente estabelecidos nas plantas de loteamento (ABREU; LIMA; FISCHER, 2018, p. 3). A forma como esse processo ocorria aparece registrada nos Termos de Aforamento que estão presentes nos livros de aforamento da Câmara Municipal de Belém ${ }^{16}$, nos quais se observa, além dos dados do enfiteuta, a data de aforamento e as características do bem aforado, assim como a quadra e o lote correspondente na planta de loteamento do bairro ${ }^{17}$.

Nos dois casos, o que se observa é que, a partir da enfiteuse e da elaboração dos Planos para os bairros - que, alguns anos mais tarde, aparecerão articulados ao Plano de Expansão de Nina Ribeiro -, a Câmara municipal passou a controlar a morfologia urbana da cidade, orientando não só a forma das quadras como também a morfologia dos lotes. Para promover esse controle, a Câmara contava com os Arrumadores, funcionários cuja responsabilidade era realizar a demarcação dos lotes in loco, em dia e hora anunciados em veículo de grande circulação, indicando diretamente ao enfiteuta quais os limites do terreno aforado e quem eram seus confinantes (ABREU; LIMA; FISCHER, 2018, p. 17).

Na imagem a seguir, é possível observar as formas de detalhamento da Planta de Loteamento da Pedreira, em articulação com a localização dessas quadras, com o Plano de Expansão de Nina Ribeiro e o levantamento da malha urbana de Belém em 1904, conforme o trabalho de Palma Muniz:

Com a Lei $n^{\circ} 82$, que dispõe sobre o processo de doação de patrimônio fundiário aos municípios, Belém recebeu, em 1899, uma parcela de terra que ficou conhecida como Segunda Légua Patrimonial, além da Vila de Pinheiro (atual distrito de Icoaraci) e da Vila do Mosqueiro, ambas de ocupação consolidada desde o século XVIII. Diferente da Primeira Légua Patrimonial de Belém, a Segunda Légua não recebeu um plano de ordenamento tal como os propostos por Palma Muniz para os municípios de Santarém, Macapá e Cametá, como se mostra na sequência deste artigo. Uma das razões foi a predominância de grandes propriedades, especialmente fazendas, nos limites da Segunda Légua, o que tornava muito reduzido o total de terras devolutas disponíveis para o patrimônio fundiário da Câmara de Belém (MUNIZ, 1904). 

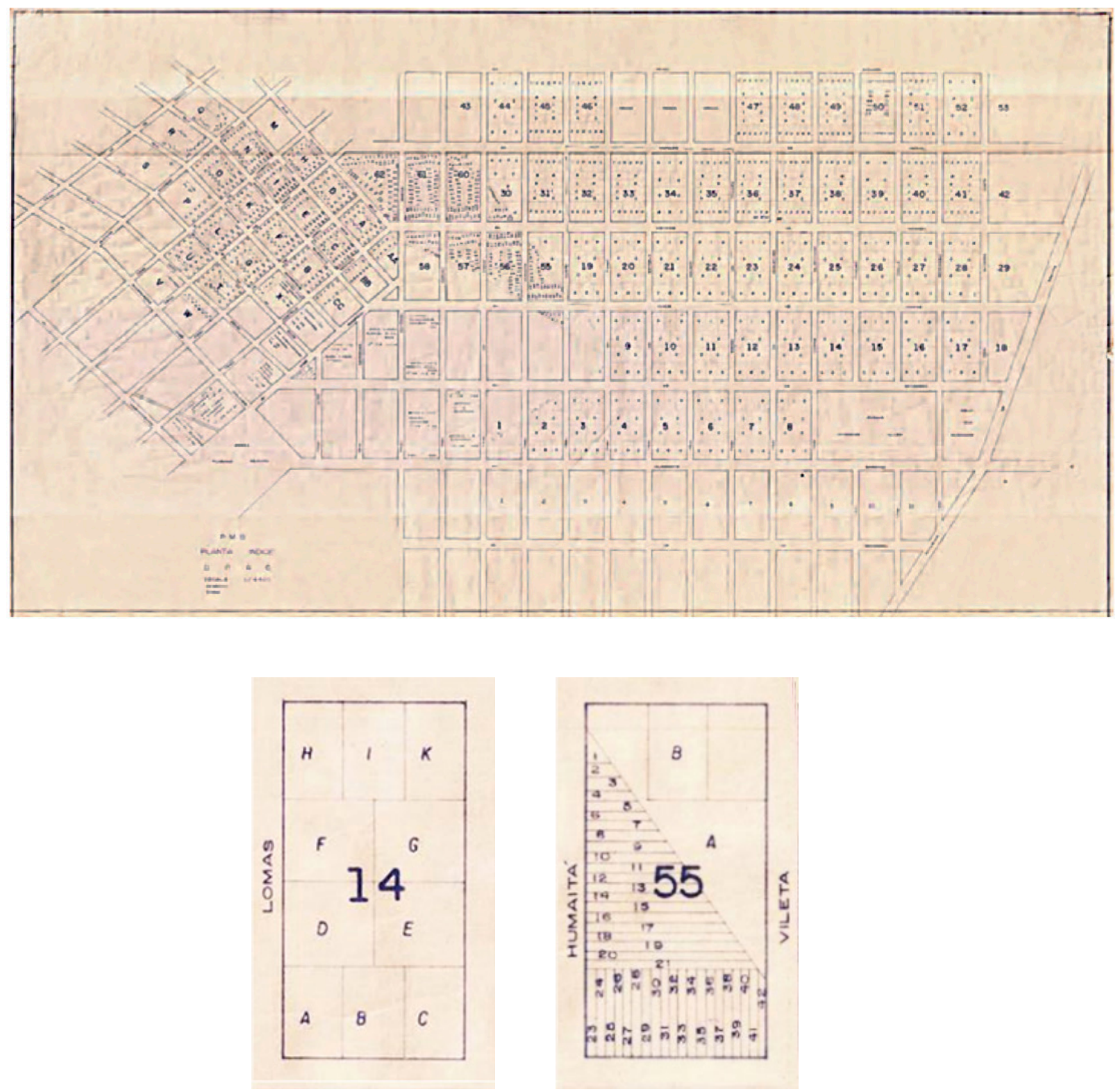

Figura 2: Planta de Loteamento para o bairro da Pedreira com seus respectivos detalhamentos morfológicos das quadras (canto superior direito) e localização na Primeira Légua Patrimonial (canto inferior esquerdo. Fonte: Elaboração do autor com base em Abreu (2018) e Muniz (1904, n. p).

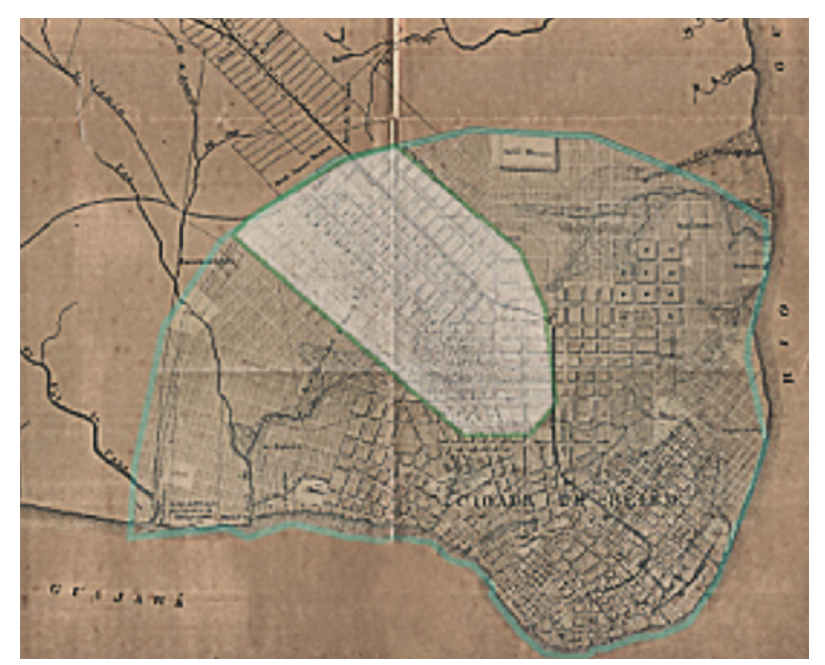


18 No caso de Chaves, Muniz (1904) cita um processo de reconhecimento de uma doação de terras realizada em momento anterior à Lei de Terras, de 1850 , a qual foi apresentada à Paróquia da região no ano de 1856. O município de Bragança, por sua vez, recebeu seu patrimônio fundiário do Ministério de Agricultura, Comércio e Obras Públicas em dois momentos distintos: 1885 e 1889.

19 Em Muniz (1904), o memorial para o plano de Cametá aparece na forma de apêndice, apenas no fim da obra.

\section{O patrimônio fundiário dos municípios paraenses e os Planos de Expansão para as cidades de Santarém, Macapá e Cametá}

Semelhante ao que ocorrera em Belém, as determinações associadas à Lei de Terras de 1850 e posteriormente às leis estaduais de 1892 e 1900 foram decisivas para que grande parte dos municípios do Estado tivesse seu patrimônio fundiário discriminado, titulado e, em alguns casos, até mesmo ampliado. A Tabela 1, compilada a partir de dados organizados por Muniz (1904), mostra que 39 municípios paraenses, dos 50 até então existentes, possuíam patrimônio fundiário e eram organizados em três grupos: i) aqueles com patrimônio discriminado e titulado; ii) aqueles com patrimônio parcialmente discriminado e titulado; iii) aqueles com patrimônio apenas concedido, mas não discriminado. O grupo mais representativo é aquele em que os municípios possuíam somente o registro de concessão do patrimônio, a maior parte dos casos faz referência à concessão de patrimônio fundiário em obediência à lei estadual $n^{\circ} 82$, de 1892, com exceção dos municípios de Bragança e Chaves, cujo patrimônio municipal havia sido reconhecido ou concedido durante o Segundo Reinado ${ }^{18}$. O grupo que possuía o patrimônio fundiário discriminado parcialmente era composto de apenas 5 municípios, e, nesses casos, a parcela não discriminada do patrimônio envolvia algum tipo de concessão relativamente recente do Governo do Estado e que ainda se encontrava em processo de demarcação. Esse é precisamente o caso de Santarém, que, apesar de possuir patrimônio fundiário discriminado desde 1873, recebeu um acréscimo ao seu patrimônio fundiário no ano de 1903.

Por fim, havia aqueles municípios que possuíam o patrimônio integralmente discriminado e titulado, totalizando 11 municípios. Em sua maioria, tratava-se de patrimônios cujo processo de concessão, ou reconhecimento, e discriminação foram organizados pelo próprio município ainda durante Segundo Reinado. Os dados apontam que não havia nenhum padrão preestabelecido sobre a dimensão desse patrimônio fundiário, fato que permitiu a ocorrência de municípios com patrimônio de pouco mais de 100 hectares, como Melgaço, no arquipélago do Marajó, e outros com patrimônio fundiário superior a 4 mil hectares, como é o caso de Cametá, na região do baixo Tocantins paraense.

Dos 39 municípios citados no livro, Palma Muniz elabora Planos de Expansão somente para as áreas urbanas de Santarém, Macapá e Cametá. Desses projetos, apenas Cametá possui o que hoje se poderia nomear de memorial justificativo e descritivo do projeto ${ }^{19}$, uma vez que os outros planos foram indicados apenas como um conjunto de diretrizes de ocupação para o patrimônio. De todo modo, do memorial escrito para Cametá, é possível extrair informações importantes sobre como Palma Muniz entendia que os municípios paraenses deveriam organizar o ordenamento territorial, urbano e rural, do seu patrimônio fundiário.

Muniz inicia o memorial do plano para Cametá realçando a importância do controle do uso e da ocupação do solo pela Câmara Municipal. Segundo ele, era necessário "dar a cada porção da superfície que constitui o patrimônio, um destino especial, designando a parte que deve ser ocupada pelas edificações e a destinada para os campos de trabalho agrícola ou industrial e de qualquer outra espécie" (MUNIZ, 1904, p. 225). O autor é claro ao destacar que a forma de o município extrair usufrutos financeiros do seu patrimônio fundiário deveria ocorrer a partir de uma divisão "bem estudada, tendo em vista principalmente duas condições essenciais, os interesses do município, aliados às disposições topográficas do patrimônio" (MUNIZ, 1904 p.226), em que a divisão do solo deveria ser discriminada entre duas espécies de terrenos: os urbanos e os rurais. 


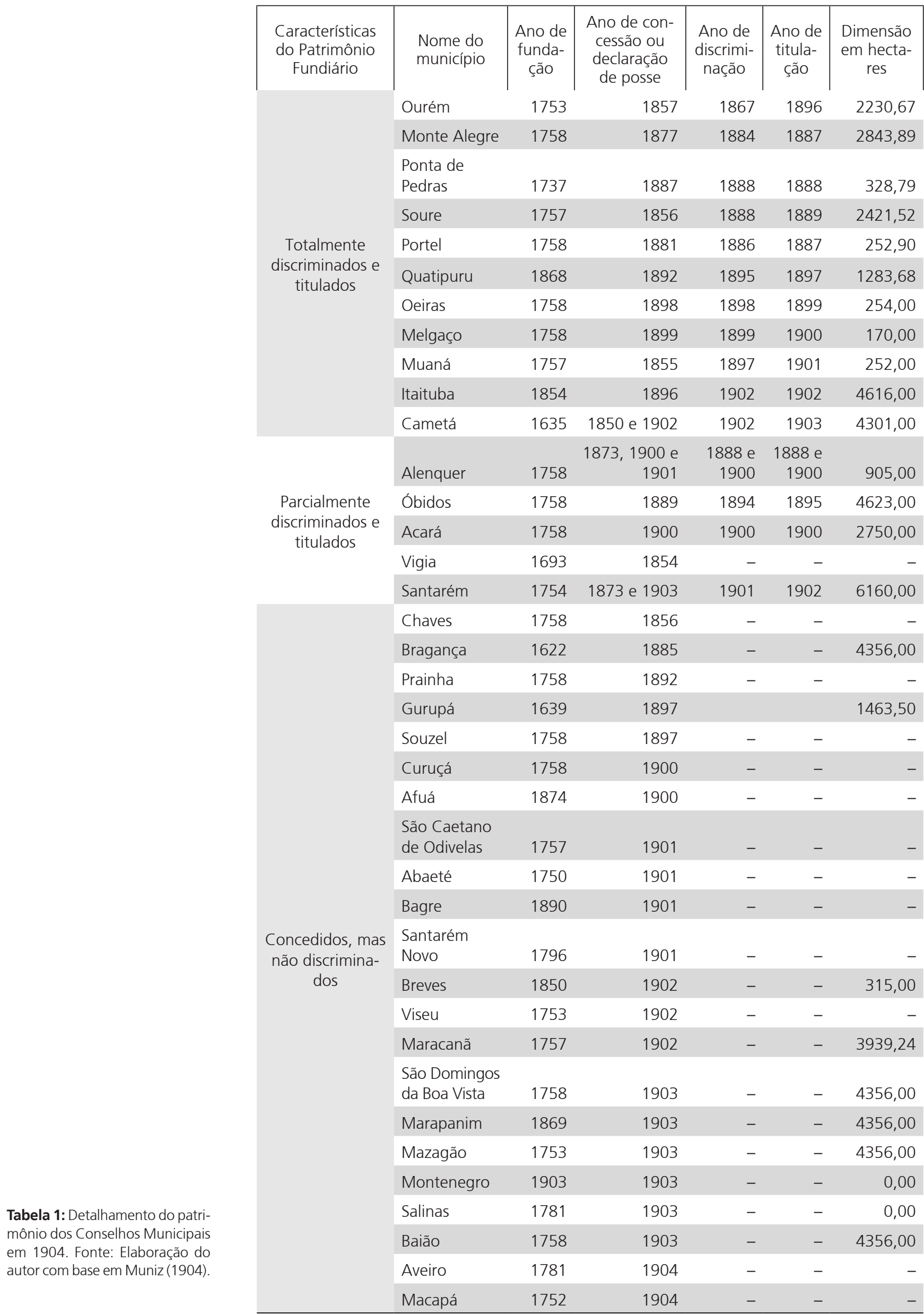


20 As medidas apresentadas ao longo do texto seguem a escala indicada em planta, que foram manualmente conferidas por mim com o uso de um escalímetro, durante a análise dos documentos originais de 1904.
O patrimônio fundiário em torno da sede do município deveria ter uma zona escolhida para a elaboração de um plano de expansão para a área urbana, reservando-se o restante do território de propriedade do município para usos rurais. O Plano de Expansão deveria conter vias públicas com " 22 metros de largura e as quadras com 180 metros de lado, podendo conter 18 lotes de 1800 metros quadrados cada um" (MUNIZ, 1904, p. 226), enquanto a zona rural deveria ser projetada com lotes agrícolas de até 15 hectares de superfície. No mesmo documento, Muniz faz referência à forma de detalhamento necessária ao plano de expansão, em que seções menores deveriam ser separadas, com plantas parciais, possivelmente de maior escala e detalhamento, aos moldes do que se verifica no caso de Belém, com a função de auxiliar no cadastro das benfeitorias realizadas pelos foreiros nos terrenos aforados.

Do ponto de vista do desenho e da morfologia das quadras, os projetos de Palma Muniz seguem o partido da malha urbana ortogonal, propagada em diversas cidades do Brasil e do mundo àquela altura. Sua regularidade se coadunava com as demandas de modernização da cidade, seja pela implantação de futuras redes subterrâneas de água e esgoto, seja pela facilidade de parcelamento do solo em lotes mais regulares e de melhor comercialização (MARX, 1991). Apesar disso, nos planos de expansão das cidades de Santarém e Cametá, assim com no de Belém, de Nina Ribeiro, é possível observar inspirações do projeto de expansão de Barcelona, desenvolvido por Ildefons Cerdá, em que pese o respeito à permanência do traçado colonial da cidade antiga, que é mantido praticamente inalterado e se articula ao novo desenho das quadras pelo prolongamento e alargamento das vias já existentes.

Nos planos para Santarém e Macapá, é possível observar uma tentativa de integração entre o núcleo antigo da cidade colonial e a malha ortogonal proposta no plano de expansão. No caso de Santarém, observa-se que tanto as ruas transversais quanto as longitudinais se originam do prolongamento das ruas já existentes, mantendo uma largura de aproximadamente 15 metros em todo o plano ${ }^{20}$. A maior parte das ruas tem início na orla da cidade e segue até encontrar-se com o grande Boulevard, que deveria circundar o Plano de Expansão, possuindo cerca de 50 metros de largura, uma característica em comum com o Plano de Expansão para Macapá, mas também presente no Plano de Expansão para Belém, de Nina Ribeiro.

No restante do que foi proposto para Santarém, a maior parte das ruas transversais deveria integrar a cidade de Santarém da orla do rio Tapajós até os limites do patrimônio municipal, com comprimentos que variavam de 1,4 quilômetros, na transversal mais longa, a 900 metros, na transversal mais curta, aproximadamente. Ademais, nota-se que apenas uma das longitudinais, construída nos limites da malha urbana existente, possuía uma largura de aproximadamente 30 metros, conectando-se a duas outras transversais de mesma largura. Com isso, a malha ortogonal resultante gerou quadras predominantemente quadradas, com cerca de 100 metros de face, além de dois conjuntos menores de quadras de formato retangular, com aproximadamente 100 metros de comprimento por 60 de largura, conforme se pode observar na figura 3 .

Além desse aspecto, é interessante notar a proposta de espaços verdes apresentada no Plano de Palma Muniz para Santarém. Ao todo estavam previstos três grandes espaços verdes, sendo dois jardins e um bosque. No projeto, os jardins são dispostos no que 
Figura 3: Plano de Expansão para núcleo urbano de Santarém. Fonte: Adaptado de Muniz $(1904$, n. p).

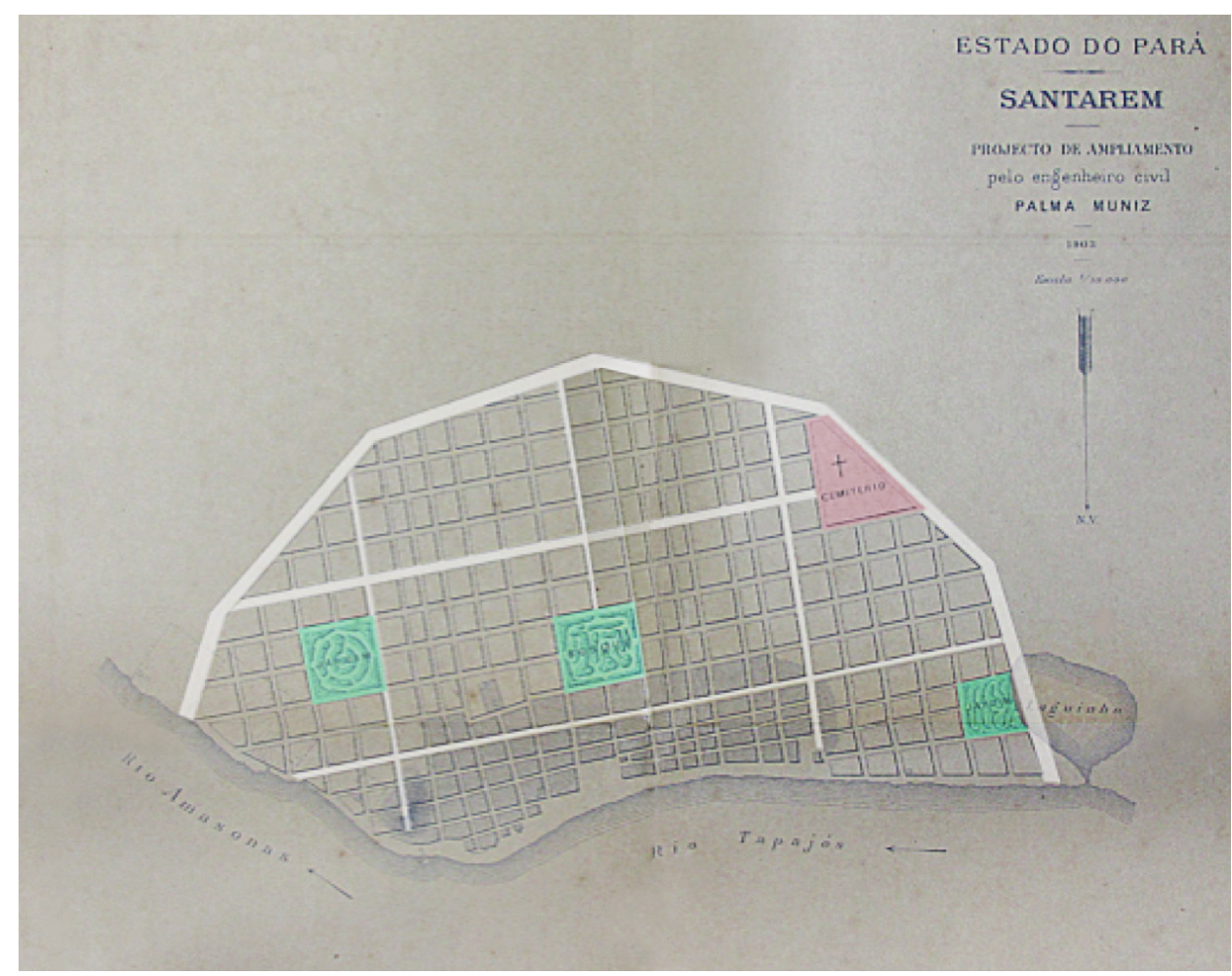

seriam as quadras novas da cidade, um em cada extremidade do plano. O jardim previsto para a parte oriental da malha urbana possuiria cerca de 48 hectares de área, enquanto que o jardim previsto para a parte ocidental do plano - nesse caso, aparentemente, conectando-se a um laguinho, conforme descrito na planta, provavelmente para fazer referência à área de várzea - possuiria uma área de aproximadamente 36 hectares. Por sua vez, o bosque que estava previsto para o centro da cidade, na confluência entre a malha urbana antiga e a nova malha ortogonal proposta, distante cerca de 400 metros da orla da cidade, ocupava uma área de aproximadamente 57 hectares. Por fim, nos limites do plano, na parte sudeste da malha ortogonal, havia ainda a previsão de um cemitério municipal, elemento comum entre os planos analisados neste artigo.

De forma semelhante, no Plano de Expansão de Macapá, as travessas longitudinais e transversais se originam da malha urbana existente e já consolidada da cidade. As ruas transversais e longitudinais apresentam largura média de 25 metros; as transversais da orla do rio Amazonas partiriam em direção ao Boulevard de Macapá, que teria largura aproximada de 40 metros e encerrava a malha ortogonal em consonância com a parcela do patrimônio municipal reservado para a expansão urbana. Além do Boulevard de Macapá, o plano também previa uma avenida central (Avenida da República), que mediria 40 metros de largura e serviria de principal via de penetração do plano, conectando a área consolidada da cidade com as novas quadras propostas. Diante desse desenho, a malha ortogonal gerada apresenta quadras predominantemente quadradas, com aproximadamente 110 metros de face, e algumas delas se ajustam à geografia da orla do rio Amazonas, conforme se pode observar na figura 4. 
Figura 4: Plano de Expansão para núcleo urbano de Macapá. Fonte: Adaptado de Muniz (1904, n. p).

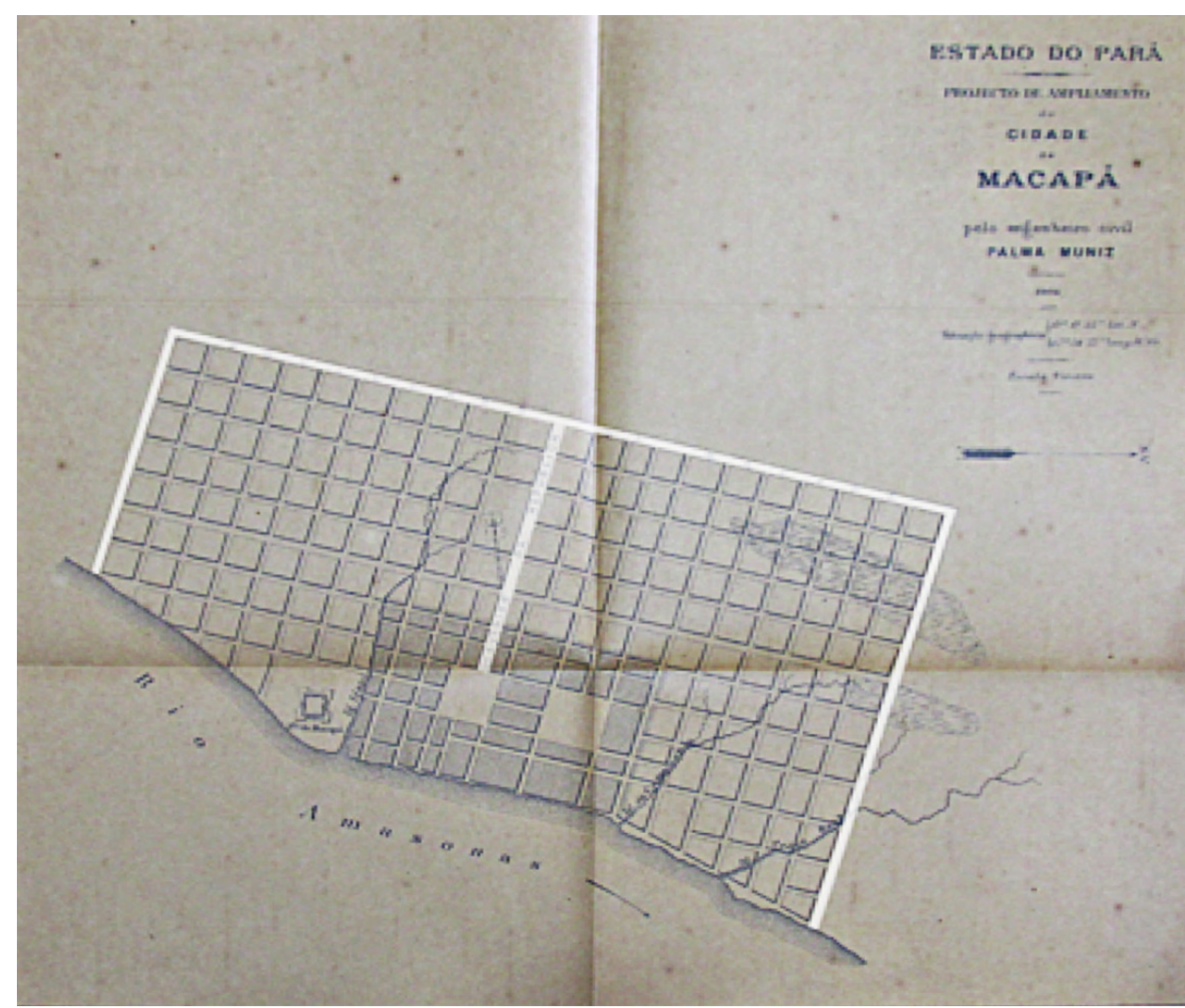

Diferente do Plano de Expansão de Santarém, em Macapá não aparecem claramente discriminados os espaços, na malha ortogonal, reservados para bosques ou jardins. Notam-se apenas duas grandes áreas abertas no interior das quadras existentes, cuja descrição não evidencia se correspondem a espaços livres que seriam criados futuramente pela Câmara Municipal, ou se representam áreas abertas que já constavam no tecido urbano de Macapá à época da proposição do Plano de Expansão. Nesse aspecto, é importante notar ainda que, em ambos os casos, a malha ortogonal proposta desconsidera a geografia típica da região, especialmente suas áreas de várzea e bacias hidrográficas urbanas, uma característica também presente no Plano de Expansão de Belém, de Nina Ribeiro. Nos três casos, nota-se que, mesmo deixando registrada no plano a extensão das áreas alagáveis, ou a ocorrência de acidentes geográficos, como morros, a malha ortogonal proposta não buscava se adequar à geografia do local, contradizendo o memorial descritivo do Plano de Cametá escrito pelo próprio engenheiro, conforme foi apresentado no início deste tópico.

A partir da observação dos dois casos, inicialmente é possível notar, por meio de técnicas de sobreposição de imagens, que a Câmara Municipal de Santarém pode ter adotado formas de ordenamento territorial para o patrimônio municipal que se orientavam pelo alinhamento previsto no Plano de Expansão de Palma Muniz. 
Figura 5: Limites do patrimônio fundiário de Santarém sobre a malha urbana atual da cidade, na parte inferior da figura uma comparação entre quadras previstas do Plano de Expansão e malha urbana atual. Fonte: Elaboração do autor com base em Muniz (1904, n. p).e Google Earth (2019).
Em ambos, porém, não é possível observar os espaços verdes previstos no plano original, tampouco os boulevares que deveriam encerrar o patrimônio municipal. No caso de Macapá, as similitudes estão menos presentes, mas é possível observar o prolongamento de algumas vias do traçado da cidade colonial, conforme previu Palma Muniz, apesar de as morfologias das quadras serem distintas, são retangulares, enquanto o plano previa quadras quadradas, com, em média, 180 metros de comprimento na face maior e cerca de 65 metros na face menor. Por outro lado, em Santarém se observa uma similitude maior entre a proporção das quadras previstas no plano e algumas quadras da malha urbana atual da cidade, com dimensões aproximadas de 180 metros em cada face, alinhando-se às dimensões recomendadas por Palma Muniz no memorial para o Plano de Expansão de Cametá, conforme se pode observar na figura 5.
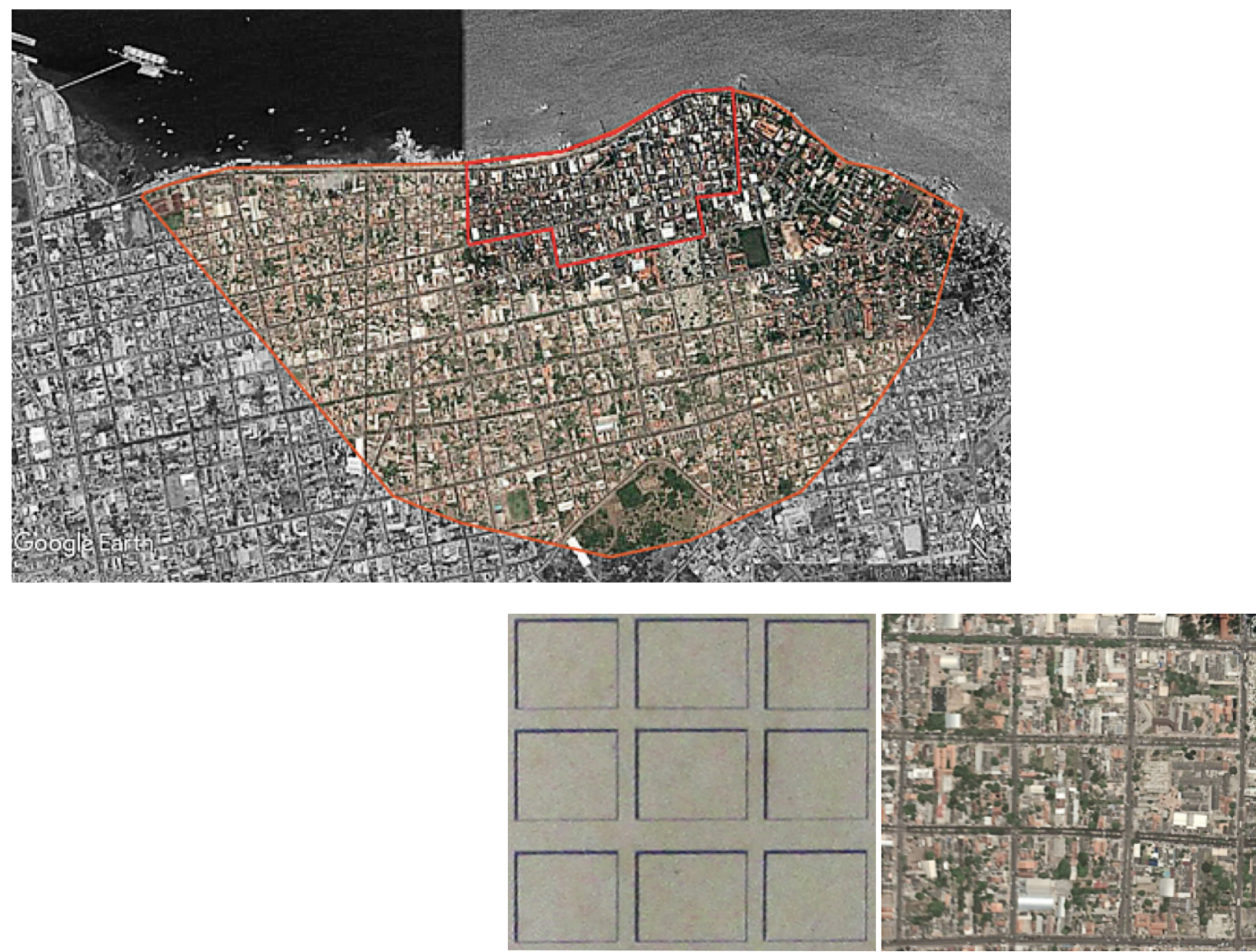
Figura 6: Plano de Expansão para núcleo urbano de Cametá. Fonte: Adaptado de Muniz (1904, n. p).

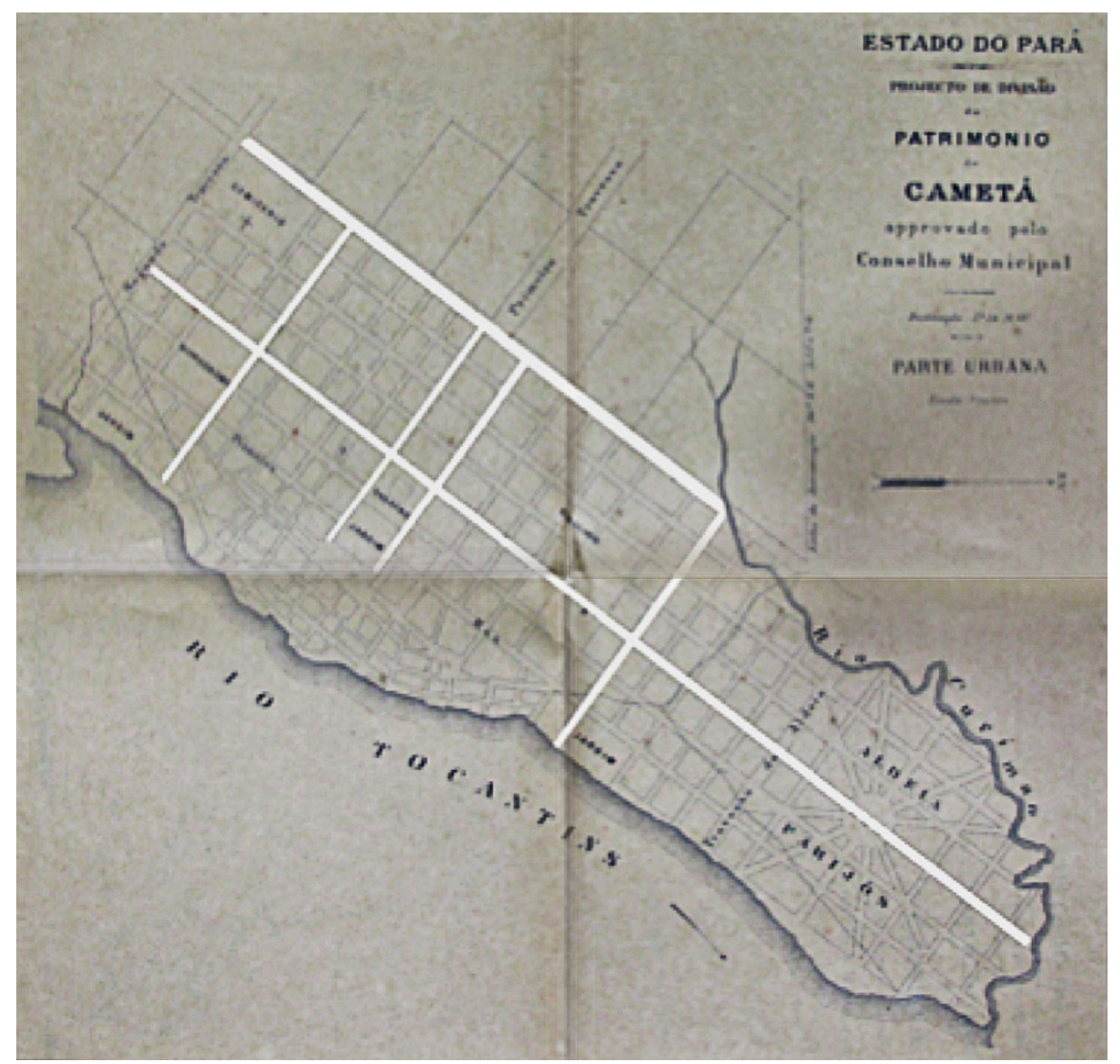

Dentre os planos elaborados por Palma Muniz, o Plano de Expansão de Cametá é o que apresenta as mais significativas particularidades, possivelmente por ter sido o único efetivamente encomendado pelo Intendente da cidade. Contudo, é o único, dentre os três planos elaborados, em que não há claramente delimitado o limite da malha urbana que corresponde à cidade existente, apesar de ser possível supor qual área corresponde à cidade colonial em virtude das diferenças na modulação do tecido urbano. Se essa hipótese for considerada, nota-se que a nova malha proposta se conecta à malha existente por meio de quatro transversais principais, com aproximadamente 25 metros de largura. Essas transversais conectam-se a outras duas travessas longitudinais de mesma largura: o Boulevard de Cametá, com cerca de 40 metros de largura e aproximadamente 4,3 quilômetros de extensão, indo de um extremo a outro do plano; e a Primeira Avenida Municipal, com aproximadamente 60 metros de largura e 2,7 quilômetros de extensão:

Conforme foi descrito no memorial que consta em Muniz (1904), o Plano de Cametá apresentou um projeto de ocupação para toda a área do patrimônio municipal, segmentando com uma Avenida (Primeira Avenida Municipal) quais os limites entre a área urbana e a área rural. Para o que deveria ser a área rural do patrimônio, Palma Muniz formulou uma proposta de loteamento, com o indicativo de estradas longitudinais e transversais de aproximadamente 100 metros de largura, para a penetração no território, conectadas à cidade de Cametá, a fim de garantir acesso a grandes glebas de 15 hectares em média, conforme se pode observar na figura 7. 


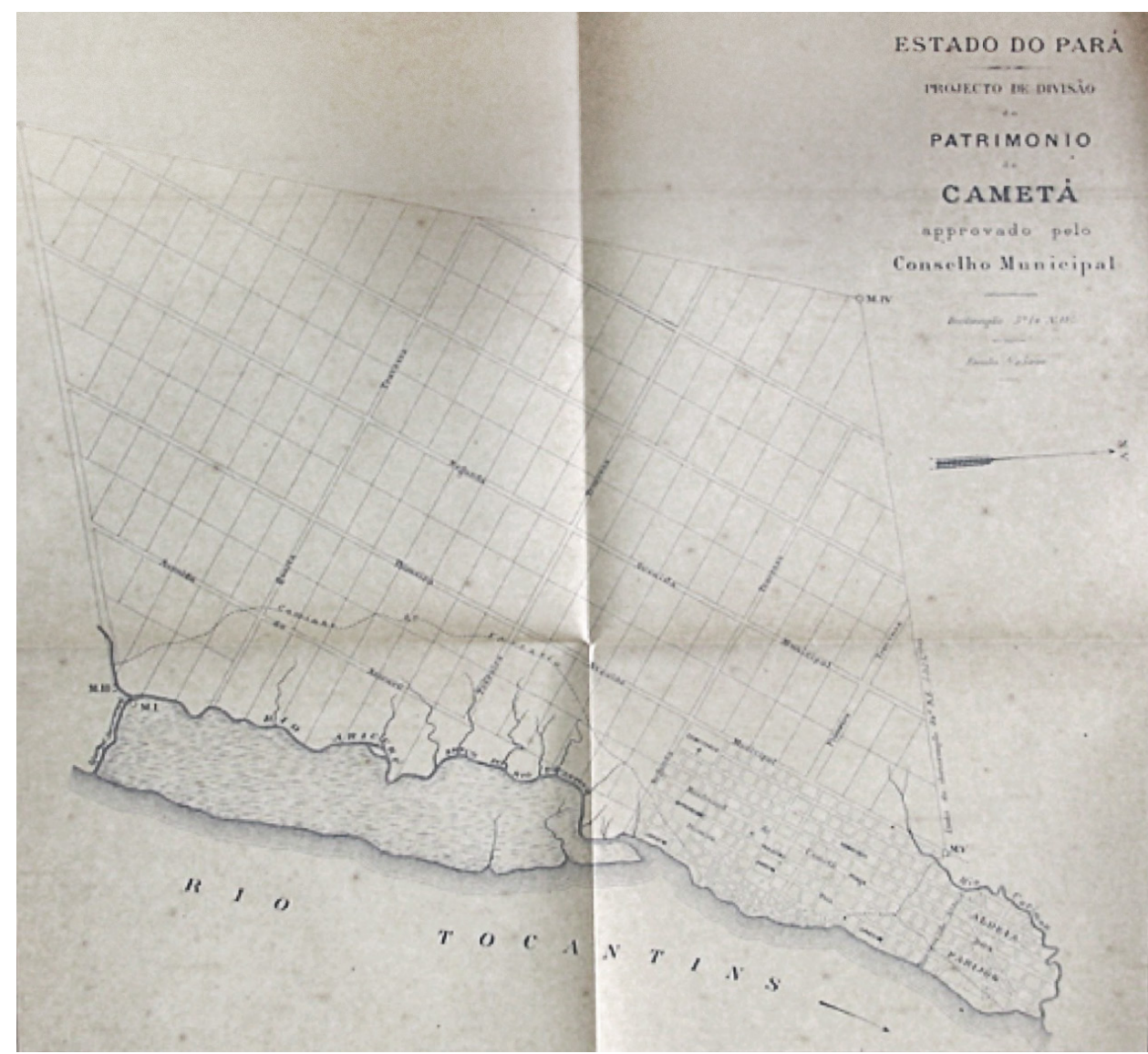

Figura 7: Plano de expansão para área rural de Cametá. Fonte: Muniz (1904, n. p).
Ainda sobre o Plano de Expansão para o núcleo urbano, a malha ortogonal que resulta da proposta de Palma Muniz possui quadras predominantemente quadradas, com aproximadamente 115 metros de face, com limites definidos pelo rio Curiman. Além disso, é notável ainda a previsão de equipamentos públicos associados à modernidade urbana da época, tais como: Hipódromo, Teatro, Corpo de Bombeiros, além de Praças e Jardins, estes últimos situados em pontos opostos da orla da cidade. Também de forma específica para o Plano de Expansão de Cametá, Palma Muniz apresenta uma proposta de parcelamento que abandona a lógica de malha ortogonal para a região do patrimônio onde havia uma aldeia de indígenas da etnia Parijós. Apenas nesse trecho do Plano, Palma Muniz adota um partido com doze ruas que convergem para uma área livre circular do bairro, no que seria o centro da aldeia. Especificamente nesse trecho, a orla da cidade é mantida livre de ocupação e em contato direto com o rio, com quadras que apresentam formas irregulares, predominantemente trapezoidais e de área variada, conforme se pode observar na figura 8. 
Figura 8: Proposta de malha ortogonal com a Aldeia dos Parijós. Fonte: Muniz (1904, n. p)

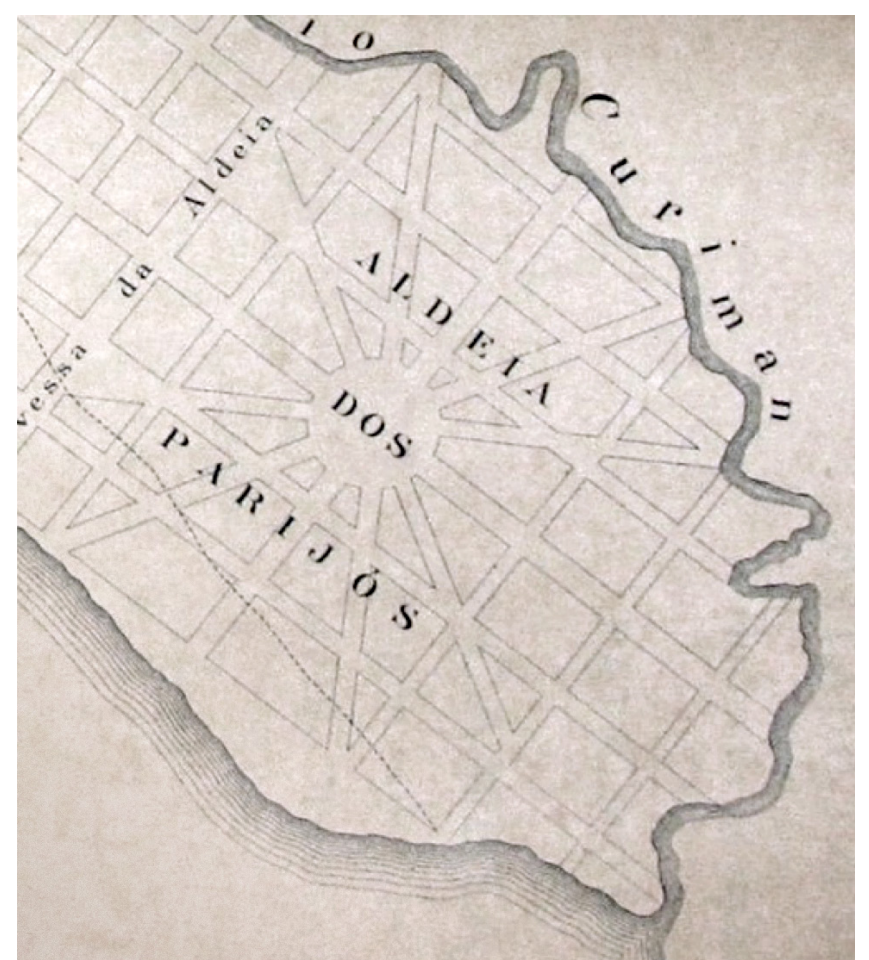

\section{Considerações finais}

Os Planos de Expansão para as cidades de Santarém, Macapá e Cametá e as evidências de uma possível execução deles, segundo novos níveis de detalhamentos na escala dos bairros, aos moldes do que ocorria em Belém no mesmo período, apontam não somente para a forma como o avanço na mercantilização da terra urbana no Pará reconfigura instituições históricas de ordenamento territorial, como a enfiteuse, como também demonstra como teria ocorrido a modernização de estruturas urbanas coloniais nos municípios paraenses, durante o ciclo gomífero.

Sem desconsiderar as críticas fartamente realizadas quanto ao caráter perverso das políticas higienistas sobre o ordenamento territorial das cidades brasileiras, durante 0 século XIX e início do XX, os casos trazidos neste artigo permitem vislumbrar um período ainda pouco evidenciado do urbanismo no Brasil, no qual o poder local, como grande proprietário fundiário, podia ditar as regras morfológicas, com o detalhamento dos Planos de Expansão ao nível dos lotes. As plantas de loteamento elaboradas para Belém, como forma de promover uma ocupação ordenada da Primeira Légua Patrimonial de Belém e seccionar o Plano de Expansão de Nina Ribeiro, são exemplos do quadro institucional que possivelmente estava presente nas Câmaras dos municípios paraenses, mas que ainda demandam novas rodadas de investigação para ir ao encontro das fontes primárias.

De fato, visualiza-se, ainda que de forma um pouco ofuscada, uma trajetória institucional que se desfaz e se apaga da memória da população urbana da região, conforme passam a valer novas estratégias de planejamento urbano, fortemente associadas às diretrizes centralizadoras do governo militar e do Serviço Federal de Habitação e Urbanismo, presentes nas cidades da Amazônia e particularmente em Belém, onde 
são formatadas instituições para planejar o ordenamento territorial da Primeira Légua Patrimonial - que se mantêm ativas até os dias de hoje.

Não obstante, vale ressaltar que a implementação efetiva da política urbana brasileira como direito social ainda depende diretamente da superação de diversos entraves associados à nossa formação histórica, inclusive aqueles relacionados à questão fundiária urbana. Nesse sentido, além da intenção de debater a expansão dos ideais de urbanismo para o interior da Amazônia, entende-se que a compreensão de particularidades da história urbana regional, que de algum modo se conectam a estruturas de longa e média duração da formação econômica e social brasileira, pode ser fundamental para pensar criticamente a eficácia dos atuais instrumentos de ordenamento territorial.

No seio da dinâmica de produção social do espaço urbano capitalista, o proprietário fundiário vem tornando-se um agente cada vez mais necessário para a sobrevivência do sistema, já que, pelo controle da morfologia da cidade, ele assegura resiliência às estruturas e relações de poder que controlam o padrão de urbanização. Na realidade urbana paraense, o embate constante, e por vezes desigual, entre quem formula as políticas urbanas de abrangência local e os agentes do capital que dependem da captura da renda fundiária para se reproduzir tem se traduzido frequentemente em leis de uso do solo cada vez mais permissíveis e negligentes à questão ambiental urbana e aos direitos sociais assegurados pela Constituição Federal.

De fato, apesar da expansão do número de municípios com Plano Diretor desde 2008, apenas a cidade de Belém possui Lei de Uso e Ocupação do Solo efetivamente operante e, ainda assim, com vicissitudes. Nesse sentido, a institucionalidade constituída em torno do ordenamento territorial desses núcleos, durante um tempo impreciso, articulando aforamento com um controle rígido sobre o alinhamento dos lotes, aponta para a possibilidade de o poder local, em regiões periféricas do sistema, deter o controle direto da morfologia da cidade por meio de outras formas de propriedade da terra urbana.

\section{Referências bibliográficas}

ABREU, P. A morfologia do plano de expansão da cidade de Belém e a estrutura fundiária do município no século XIX. 2018. 206 f. Dissertação (Mestrado em Arquitetura e Urbanismo)- Programa de Pós-graduação em Arquitetura e Urbanismo, Universidade Federal do Pará, Belém, 2018.

ABREU, P.; LIMA, J. J.; FISCHER, L. Aforar, arrumar e alinhar: a atuação da Câmara Municipal de Belém na configuração urbano-fundiária da cidade durante o século XIX. Anais do Museu Paulista: História e Cultura Material, v. 26, p.1-55, set. 2018. Disponível em: https://www. revistas.usp.br/anaismp/article/view/145462/148851. Acesso em: 20 fev. 2021.

BENÉVOLO, L. História da cidade. 6. ed. São Paulo: Perspectiva, 2015, p. 571-578.

BRASIL. Lei $n^{\circ}$ 601, de 18 de setembro de 1850. Dispõe sobre as terras devolutas do Império. Rio de Janeiro: Secretaria de Estado dos Negócios do Império, [1850]. Disponível em: <http://www.planalto.gov.br/ccivil_03/leis/l0601-1850.htm>. Acesso em: 20 fev. 2021.

CALABI, D. História do urbanismo europeu: questões, instrumentos, casos exemplares. São Paulo: Perspectiva, 2012.

CARVALHO, J. M. de. República, democracia e federalismo no Brasil, 1870-1891. Varia Historia, Belo Horizonte v. 27 n. 45 p. 141-157, 2011.

CAVALCANTE, J. L. A Lei de terras de 1850 e a reafirmação do poder básico do Estado sobre a terra. Histórica, São Paulo, ano 1, n. 2, p.1-7, jun. 2005. 
COSTA, F. A. Formação rural extrativista na Amazônia: os desafios do desenvolvimento capitalista (1720-1970). Belém: NAEA, 2012.

DUARTE, C. Belém do Pará, na virada do século XIX: modernidade no plano urbanístico de expansão da cidade. 1997. Dissertação (Mestrado em Arquitetura e Urbanismo) - Universidade Federal do Rio de Janeiro, Rio de Janeiro, 1997.

FERREIRA, E. Guerra sem fim: mulheres na trilha do direito à terra e ao destino dos filhos (Pará - 1835-1860). 2010. Tese (Doutorado em História) - Pontifícia Universidade Católica de São Paulo, São Paulo, 2010.

FISCHER, L.; BENATTI, J. Análise dos aforamentos municipais concedidos entre 1815-1930. Relatório de Pesquisa, Belém, 2017.

FONSECA, C. D. Arraiais e vilas d'El Rei. Espaço e poder nas Minas setecentistas. Belo Horizonte: Editora da UFMG, 2011.

HARVEY, D. Paris, Capital da Modernidade. São Paulo: Boitempo, 2015.

HERCE, M. O negócio da cidade: evolução e perspectivas da cidade contemporânea. Rio de Janeiro: Mauad X, 2015.

LEME, M. C. da S. Urbanismo no Brasil 1895-1965. São Paulo: FUPAM/FAUUSP/Studio Nobel, 1999.

MARX, M. Cidade no Brasil: terra de quem? São Paulo: Nobel/EDUSP, 1991 (Coleção Cidade Aberta).

MORAES, T. A engenharia da história: natureza, geografia e historiografia na Amazônia. 2009. Dissertação (Mestrado em História) - Programa de Pós-graduação em História, Universidade Federal do Pará, Belém, 2009.

MUNFORD, L. A cidade na história: suas origens, desenvolvimento e perspectivas. São Paulo: Martins Fontes, 2004.

MUNIZ, J. de P. Índice Geral dos Registros de Terras. Belém: Imprensa Oficial, 1907.

Patrimônio dos Conselhos Municipais do Estado do Pará. Paris, Lisboa: Aillaud \& Cia, 1904.

RIBEIRO, E. E.; ALVES, J. J. Condições de criação da Escola de Engenharia do Pará: a valorização e formação científica dos engenheiros (1870 -1931). Revista Brasileira de História da Ciência, Rio de Janeiro, v. 8, n. 1, p. 57-64, jul./dez. 2015.

SAMPAIO, P. de A. Terras devolutas e latifúndio. Economia e Sociedade, Campinas, v. 6, p. 193-198, 1996.

SEGAWA, H. Arquiteturas no Brasil: 1900-1990. São Paulo: Edusp, 2014.

SILVA, H. Socialização da natureza e alternativas de desenvolvimento na Amazônia Brasileira. 2017. Tese (Doutorado em Economia) - Centro de Desenvolvimento e Planejamento Regional, Universidade Federal de Minas Gerais, Belo Horizonte, 2017.

SILVA, L. O. Terras devolutas e latifúndio: efeitos da lei de 1850. Campinas: Editora da UNICAMP, 1996, p. 265-272.

STOLL, E.; FISCHER, L.; FOLHES, R. Recenser la propriété en Amazonie brésilienne au tournant du XXe siècle. Histoire \& mesure, v. 32, n. 1, 2017.

VENTURA NETO, R. da S. Notas sobre a formação socioespacial da Amazônia. Nova Economia, v. 30, n. 2, p. 579-603, 2020.

VICENTINI, Y. Cidade e história na Amazônia. Curitiba: Editoria UFPR, 2004.

WEINSTEIN, B. A borracha na Amazônia: expansão e decadência (1850-1920). São Paulo: Hucitec/Edusp, 1993, p. 233-235. 